\title{
Single Colour Trademarks not Only on the Current Czech Market
}

\author{
Anastasiia Dmitrieva ${ }^{1}$; Radka MacGregor Pelikánová ${ }^{2}$ \\ ${ }^{1}$ Anglo-American University of Prague, \\ Letenská 5, 11800 Prague 1, Czech Republic \\ ${ }^{2}$ University of West Bohemia, Faculty of Law, Department of Commercial Law, \\ Sady Pětatřicátníků 14, 30614 Plzeň, Czech Republic \\ e-mail: ${ }^{1}$ ana.dmitrieva@aauni.edu; ${ }^{2}$ radkamacgregor@yahoo.com
}

\begin{abstract}
Post-modern global society is marked by a highly intense competition in which proper referencing is critical. Indeed, a competitive advantage is useless without a legally protected method of linking the undertaking to its products. This method par excellence takes the form of a trademark, which is both a referencing tool and an extremely valuable intangible asset. Each jurisdiction provides for the registration of trademarks and over time the registries have become densely filled, i.e. it is extremely difficult to find a new, attractive and universal sign able to be registered in several jurisdictions and thus become a global trademark understood and recognized world-wide. To address this issue linked to conventional trademarks, both the EU law and the Czech law newly explicitly allow unconventional trademarks, such as colours. The goal of this paper is very innovative and pioneering, namely to research primary and secondary data about single colour Czech trademark registrations and related trends and to provide indices to confirm or to reject the hypothesis that single colour trademarks are perceived both by the fields of law and economics as more than a viable option for referencing and marketing, as well as being an asset.
\end{abstract}

\section{Keywords}

Colour; Trademarks; Registration; Distinctiveness.

\section{Introduction}

Post-modern global society is marked by a clash of contradictory values and priorities [13] and highly intense competition on national, regional [11] and even global levels. Indeed, as a consequence of globalizing markets, markets and competition in them do not end at national borders [7]. The competitive advantage is a key phenomenon and undertakings and businesses seek to obtain it, maintain it and make it public. Hence, it is critical to appreciate and appropriately use an effective and efficient method of linking them to their superior goods and services. The intellectual property law offers a world-wide recognition option enjoying legal protection - trademarks. Naturally, despite the more than 100 years long international harmonization via the Paris Convention and Madrid System, and other treaties managed by the World Intellectual Property Organization ("WIPO"), national laws on trademarks demonstrate differences. However, it seems that the distinctiveness is a key capacity which each and every sign must satisfy to be able to be registered in any jurisdiction and thus to become a trademark enjoying a strong legal protection and making sure that, without the consent of a trademark owner, nobody will be allowed to use such a trademark for pertinent goods and services.

Traditional trademarks AKA conventional trademarks include word marks, figurative marks (images) and figurative marks with letters. Their importance and popularity along with the 
need of registration led to the status quo when basically "everything attractive is taken" [3]. Hence especially SMEs have been facing the difficult issue - how to find a good and attractive sign, which is capable to be registered as a trademark, and has not yet been registered. In other words, the density of the conventional trademark registrations makes it extremely difficult to get a new attractive trademark to be used on goods and services of a new undertaking.

The economic reality confronted the law rigidity and for last two decades in the EU, including the Czech Republic, businesses have been fighting to get new and attractive unconventional trademarks. Their endeavours were oriented in three main lines - colour, signs, smells and 3D. These are important elements which can aid in brand promotion, thus creating a strong product association and positive feelings among the customers and, therefore, should prove to be an advantage in the marketplace.

Law is an image of society, and the political and especially economic demands shape the law, hence both the EU trademark law and the Czech law underwent big changes in this respect reaching the extent of a reform. The EU law on trademarks firstly allows the registration of EU trademarks with the European Union Intellectual Property Office ("EUIPO") and grants them the validity in the entire EU, including the Czech Republic, and secondly harmonizes the national law on national trademarks valid only in the given EU member state, e.g. the Czech national law on trademarks is harmonized and provides that the Industrial Property Office of the Czech Republic ("CZ IPO") registers Czech national trademarks valid only in the Czech Republic and eventually able to have protection in other countries via WIPO and the Madrid System. Both the EU law on trademarks and the Czech law on trademarks have been recently reformed, even in the respect of unconventional trademarks. So, is the Rubicon crossed? Do the Czech law and the EU law and economic disciplines allow and even perhaps welcome colour trademarks? Many more questions touching public policies, good manners [12] of competition, both ethical and hard business concerns emerge. However, already the confirmation of the hypothesis, that both laws applicable in the territory of the Czech Republic open the door to the economic drive for colour trademarks, provides indices about the current status of colour trademarks and even what their future might be on the Czech market, and perhaps even in the entire EU.

\section{Statement of a Problem and Aims of Research}

A market needs brands for consumer orientation and a strong brand identity is an important factor for a brand's success [6]. The trademark law is relatively harmonized in the EU and even in the global context due to both important international treaties as well as the crossborder reality of our cyber life and business operation. Multi-national, national, regional, local and other types of businesses are more and more looking for a competitive advantage and, once reached, it is absolutely critical that everybody from all over can link this undertaking to such a superior product. Hence, registering an identical trademark in various jurisdictions is practically a must. Both the EU law and the Czech law require that a sign, to be registered as a trademark, must be able to meet the definition of a trademark and perform functions of a trademark, even ultimately become an investment and/or asset [9]. The hallmark of this test is the ephemeral and eternally discussed concept of distinctiveness. Boldly, a distinctive sign should work for the owner (being his protected property) and for consumers (being a reference and source of information for them) [8]. The 20th century was dominated by the law and economic stream recognizing only signs which are nowadays called conventional trademarks. Neither the EU law nor the Czech law explicitly allowed or rejected colour trademarks, but they both confronted them with an almost insurmountable obstacle distinctiveness. However, the wind started to blow in the opposite direction over two decades 
ago in the USA with Qualitex Co. v Jacobson Products Co. (1995) [4] and it seems that the world follows this new pattern. Currently, there is not any doubt that consumers are able to recognize without difficulty a colour as an identifier of a commercial source [1] even if the colour is used on a barely visible bottom part of the product, see the famous "red sole mark" case Christian Louboutin S.A. v. Yves Saint Laurent Am. Holdings, Inc. 696 F. 3d 206, 212 (2nd Cir. 2012) [16]. In addition, courts are inclined to protect against copycat activities only highly distinctive features of brands [15] and so a colour as a mere part of a logo trademark is highly vulnerable.

Hence, the aim of this research is to identify and analyze the Czech law and the EU law currently valid and applicable in the territory of the Czech Republic and figure out whether they allow colour trademarks and how the large public, especially businesses, react to them. Due to the extent limitation, this paper focuses only on the EU trademarks and "totally" Czech trademarks, i.e. the EU law on trademarks and the Czech law on trademarks, i.e. it does not cover WIPO treaties and international trademark venue to the Czech Republic and to the Czech market.

To put it another way, the static-substantive problem is whether the EU and Czech legal frameworks truly and genuinely allow registration of colour signs as trademarks and grant them a legal protection on the Czech market. The dynamic-procedural problem is whether these legal provisions are dead letters or really useful vehicles, namely, what is the result of their application of the EUIPO and CZ IPO. The authors of this paper deeply appreciate colour trademarks and are convinced that the importance and potential massive impact of colour trademarks strongly litigate for seriously addressing both problems - whether they are doable and whether they are really done. Hence, the authors conducted this very first pioneering research and study on the single colour trademarks in the Czech Republic - what is their legal framework? How many are there? Who are their owners? What goods and services are registered? What do they look like? Can we already see any patterns?

\section{$2 \quad$ Sources and Methods}

This paper is the result of a multi-disciplinary research of primary and secondary sources able to generate data for addressing the stated aims and dual hypothesis. Regarding primary sources, a statute, cases and register exploration and field observation were performed and assessed. Regarding secondary sources, an abundance of Czech, as well as foreign, academic and scientific literature focusing on legal or business aspects was studied. The first hypothesis, $H_{1}$, to be confirmed or rejected is that both the EU law and the Czech law allow single colour trademarks, i.e. they do not prohibit them and they recognize their distinctiveness potential. The second hypothesis, $\mathrm{H}_{2}$, to be confirmed or rejected is that businesses go for single colour trademarks, i.e. they file applications for colour trademarks, succeed in obtaining and using colour trademark with the Czech legal protection, i.e. monopolize the use of a colour as a marketing and referring vehicle for their products on the Czech market. In addition, auxiliary and related questions about the number, types, owners and covered goods and services of these single trademarks can be answered. Perhaps, even certain trends might be revealed.

A matching battery of appropriate methods including description and comparison is employed. Logically, the preference was given to the register mining and field observation along with analysis of statutes, cases and academic literature over econometric and mathematical methods. Nevertheless, the qualitative predominance and argumentative legal reasoning [10] is complemented by the quantitative pointing out the total number of valid colour trademarks and length of proceedings leading to them. In sum, the Meta-Analysis and relevancy of the legal and economic perspectives cannot be overlooked, so it must include 
both deductive and inductive aspects [5] and the static and dynamic approach deals both qualitative and quantitative aspects and their juxtaposition should not be overplayed [14].

\section{The Current EU Law and the Czech Law on Colour Trademarks - a Single Colour Can Pass the Distinctiveness Test}

The law on trademarks seeks to ensure market transparency [1], protects and facilitates all trademark functions and creates a valuable asset. As mentioned above, the law applicable regarding trademarks on the Czech market belongs basically to two systems, either to the EU law system with the EUIPO or to the Czech national system with the CZ IPO. In addition, the international law on trademarks with WIPO institutional framework comes into the picture, but the critical role for colour trademark registrations is played by the EU law and the Czech national law. They both allow colour trademarks, focus on their distinctiveness and partially non-functionality as well.

\subsection{The EU Law on Colour Trademarks - 2015 Reform Provides for Colour Trademarks and Allows Distinctive Single Colour Trademarks}

Since there are three types of EU law competencies - conferred exclusive, conferred shared and others, the EU law on trademarks has two branches - regulations that deal with EU trademarks previously granted by the OHIM and now EUIPO in Alicante (conferred exclusive) and directives that deal with the harmonization and approximation of all EU member states' national laws on trademarks (conferred shared) [3]. Traditionally, colour trademarks were omitted in EU regulations and directives and OHIM has interpreted the EU law on trademarks in the light of the internal single market, i.e. the distinctiveness has to be established vis-à-vis the EU population at large. Hence, until 2015, the EU law was rather silent about colour trademarks, but still not excluding them, naturally providing the massive awareness of such a colour sign linking the undertaking and products was spread all over on the single internal market. At the same time, trademarks have been always important for the EU and they have received a lot of attention, especially due to their capacity to support the proper functioning of the single internal market [1].

The 2015 EU reform brings dramatic changes in the registration of trademarks and particularly colours, which are explicitly admitted. Namely, pursuant to Art.4 of Regulation (EU) 2015/2424 of the European Parliament and of the Council of 16 December 2015, Official Journal of the European Union, L 341/21 amending Regulation 207/2009:

An EU trademark may consist of any signs, in particular words, including personal names, or designs, letters, numerals, colours, the shape of goods or of the packaging of goods, or sounds, provided that such signs are capable of: (a) distinguishing the goods or services of one undertaking from those of other undertakings; and (b) being represented on the Register of European Union trademarks, ("the Register"), in a manner which enables the competent authorities and the public to determine the clear and precise subject matter of the protection afforded to its proprietor.

Similarly, pursuant to Art.3 of Directive (EU) 2015/2436 of the European Parliament and the Council of 16 December 2015 to approximate the laws of the Member States relating to trade marks, Official Journal of the European Union L 336/1:

A trade mark may consist of any signs, in particular words, including personal names, or designs, letters, numerals, colours, the shape of goods or of the packaging of goods, or sounds, provided that such signs are capable of: (a) distinguishing the goods or services of one undertaking from those of other 
undertakings; and (b) being represented on the register in a manner which enables the competent authorities and the public to determine the clear and precise subject matter of the protection afforded to its proprietor.

This novelization is progressively taking effect during several years and no case law has been established yet. From the old case law, it should be pointed out e.g. C-104/01 Libertel, C50/01-55/01 Linde, according to which the CJ EU assumes that consumers do not recognize the colour as an identifier of commercial source, but this assumption can be (allegedly to easily) reversed [1].

Indices about the interpretation and applications of the post-reform EU law on trademarks can be detected based on the wording of EUIPO Guidelines for examination in the Office, Part B from 2017, presenting the view that a colour alone cannot be considered as inherently distinctive and its registration is possible only with a demonstration of an acquired distinctiveness among customers, while a colour combination can be inherently distinctive. However, it is crucial for applicants that the more colours the mark contains, the less distinctive it is, because it is not easy for customers to remember and represent them all in the right sequence. Similar to the USA functionality doctrine, probably even the post-reform EU law does not allow a colour trademark reflecting the nature of goods and services, e.g. it seems impossible to establish the distinctiveness of the colour green as a trademark for an undertaking producing or commercializing Bio products, nor the colour white for the bridal industry or, on the other side of the coin, black for funeral services.

\subsection{The Czech Law on Trademarks - 2003 Provides for a Single Colour Trademark with Certain Distinctiveness}

The Czech law, until 2003, i.e. the Act No. 37/1995 Coll., on trademark, defined in its Art. 1 a trademark as

\section{"a sign consisting of words, letters, numbers, pictures or shape of a product or its package, possibly their combination, designed ...",}

which induce the positivistic interpretation and application of this provision as a ban on anything else, i.e. as a prohibition of a colour trademark. However, international and EU trends have been increasing and the preparation of the Czech accession to the EU, finalized in 2004 , contributed to it. This was the very background setting of the milestone case of "Milka - Lilac/violet" which ultimately ended with the registration of one single colour trademark and with curtailing of copycat mischievous imitation activities [15].

The new Czech Act on trademarks, i.e. Act No. 441/2003 Coll. ended all doubt and stated in its Article 1 that any sign can be a trademark if it can be represented graphically and particularly by colours, see

"Under the terms of this Act, a trademark may consist of any sign capable of being represented graphically, particularly words, including personal names, colour, designs, letters, numerals, the shape of goods or their packaging, provided that such sign is capable of distinguishing goods or services of one person from those of another person."

In the context of the EU law, it is worthy to observe that the Czech national law mentions "colour" in the singular - which is perhaps at least positive - and goes ahead and even surpasses the EU law mentioning the colours in the plural. Hence, at least hypothetically, it can be argued that the Czech national law explicitly and expressly welcomes even single colour trademarks, while the EU law rather goes for a combination of colours. Nevertheless, 
the ultimate distinctiveness test and further harmonization trends along with the single market reality will probably wipe off this linguistic difference.

\section{Colours and Single Colour Trademarks Protected on the Czech Market}

As indicated above, as of $15^{\text {th }}$ June 2017 there were 303 colour trademarks valid for the Czech Republic and thus able to provide legally protected labelling and referencing to their goods and services on the Czech market. Only 5 of these 303 are colour trademarks filed originally with the CZ IPO, i.e. only for the Czech market. The remaining 298 colour trademarks are valid in the Czech Republic via the operation of the EU law, i.e. they are EU colour trademarks valid for the entire single internal market, i.e. as well for the Czech market.

\subsection{Colours and Single Colour Trademarks' Registrations Status Quo - 28 Winners}

As of 15th June 2017, the Czech IPO had in its official register of valid (already registered) colour trademarks a total of 303 entries, i.e. 303 colour trademarks - see www.upv.cz and https://isdv.upv.cz/webapp/webapp.oza.formular. However, a closer scrutiny provides very illustrative and unexpected information bringing more light in this arena.

Firstly, 298 colour trademarks of these 303 are colour trademarks registered by the OHIM/EUIPO and only five are "totally" Czech colour trademarks, i.e. their application was filed with CZ IPO and their validity was (originally) only for the Czech market. Secondly, the "oldest" of these 303 colour trademarks, it is the only colour trademark with a priority since 1995, the above mentioned 31336 "Milka - Lilac/violet" (Pantone E 176-4" and "E 176-3") of Kraft Foods Schweiz Holding GmbH for chocolates, pralines, chocolate products and chocolate goods from the Nice class 30. Hence, the year of 1995 was the (re)start of the colour trademark, not only in the US [4], but in Europe as well and this has created a certain tension. Thirdly, out of the 303 colour trademarks, only one half consists exclusively of a colour or colours, i.e. another half includes some image, 3D and other elements. Fourthly, out of these approximately 150 truly colour and colours trademarks, only 28 are a single colour trademark. The oldest of them has again been the "Milka - Lilac/violet" since 1995 and the newest is the "Zentiva-Pink/Red" (Pantone 225C). Out of these 28 single colour trademarks, only four were originally filed with the Czech IPO, i.e. they are "totally" Czech; and the remaining 24 came from OHIM, newly EUIPO, i.e. they are EU trademarks protected on the territory of the EU and protecting (labelling of) goods and services on the single internal market, i.e. as well on the Czech market. Table 1 demonstrates which these lucky single colour trademarks recognized as distinctive and thus having a legal monopoly for the use of the given colour for the protected goods and services from the indicated Nice class are, and who their owners are. 
Tab. 1: Czech single colour trademark registered and valid on 15th June 2017

\begin{tabular}{|c|c|c|c|c|c|}
\hline Trademark & Colour & Colour & Priority & Owner & Protected goods and services \\
\hline $\begin{array}{c}\text { EUIPO } \\
31336\end{array}$ & & Lilac/Violet & 1995 & $\begin{array}{l}\text { Kraft Foods, } \\
\text { CH }\end{array}$ & 30 chocolate \\
\hline $\begin{array}{l}\text { EUIPO } \\
212787\end{array}$ & & Pink/Magenta & 1996 & $\begin{array}{c}\text { Deutsche } \\
\text { Telecom, GE }\end{array}$ & $\begin{array}{c}38 \text { telecommunication } \\
42 \text { designing installations }\end{array}$ \\
\hline $\begin{array}{l}\text { EUIPO } \\
396176\end{array}$ & & Dark Yellow & 1996 & $\begin{array}{l}\text { Northern } \\
\text { Tech., US }\end{array}$ & $2,16,17$ anticorrosion \\
\hline $\begin{array}{l}\text { EUIPO } \\
655019\end{array}$ & & $\begin{array}{l}\text { Canary } \\
\text { Yellow }\end{array}$ & 1997 & $\begin{array}{c}\text { 3M Company, } \\
\text { US }\end{array}$ & 16 self-stick notes, stationery \\
\hline $\begin{array}{l}\text { EUIPO } \\
747501\end{array}$ & & Green & 1998 & $\begin{array}{l}\text { Vanguard, } \\
\text { TM, US }\end{array}$ & $\begin{array}{c}39 \text { automobile rental and } \\
\text { services }\end{array}$ \\
\hline $\begin{array}{l}\text { EUIPO } \\
773630\end{array}$ & & Orange-Red & 1998 & $\begin{array}{l}\text { KWS SAAT } \\
\text { SE, GE }\end{array}$ & $\begin{array}{l}42 \text { technical and business } \\
\text { consultancy }\end{array}$ \\
\hline $\begin{array}{l}\text { EUIPO } \\
867408\end{array}$ & & Aubergine & 1998 & $\begin{array}{c}\text { Rexnord Flat } \\
\text { Top .., NL }\end{array}$ & 7 conveyor components \\
\hline $\begin{array}{l}\text { EUIPO } \\
962706\end{array}$ & & Brown & 1998 & $\begin{array}{l}\text { United Parcel } \\
\text { Service, US }\end{array}$ & 39 transport, packaging \\
\hline $\begin{array}{c}\text { EUIPO } \\
1029552\end{array}$ & & Blue & 1998 & \begin{tabular}{|c|} 
Chep \\
Technologie, \\
AU
\end{tabular} & 20,39 pallets made of wood \\
\hline $\begin{array}{c}\text { EUIPO } \\
1292705\end{array}$ & & Light Orange & 1999 & $\begin{array}{c}\text { Stroh Austria, } \\
\text { AT }\end{array}$ & $\begin{array}{l}33 \text { rum and beverages } \\
\text { containing rum }\end{array}$ \\
\hline $\begin{array}{c}\text { EUIPO } \\
2550457\end{array}$ & & $\begin{array}{l}\text { Canary } \\
\text { Yellow }\end{array}$ & 2002 & $\begin{array}{c}\text { 3M Company, } \\
\text { US }\end{array}$ & 16 self-stick notes, stationery \\
\hline $\begin{array}{l}\text { EUIPO } \\
379336\end{array}$ & & Purple & 2003 & $\begin{array}{c}\text { Marks } \\
\text { Petcare, UK }\end{array}$ & 31 Foodstuffs for cats \\
\hline $\begin{array}{c}\text { EUIPO } \\
3425311\end{array}$ & & Red & 2003 & $\begin{array}{l}\text { Hilti, AG, } \\
\text { GE }\end{array}$ & $\begin{array}{l}7 \text { Drill hammers for } \\
\text { constructions }\end{array}$ \\
\hline $\begin{array}{l}\text { CZ IPO } \\
304707\end{array}$ & & Red & 2004 & $\begin{array}{l}\text { Vodafone, } \\
\text { CZ }\end{array}$ & $\begin{array}{l}38 \text { mobile telecommunication } \\
\text { services }\end{array}$ \\
\hline $\begin{array}{c}\text { EUIPO } \\
4248399\end{array}$ & & Turquoise & 2005 & $\begin{array}{l}\text { Husqvarna, } \\
\text { SE }\end{array}$ & $\begin{array}{c}\text { 7, } 8 \text { garden equipment } \\
12,20 \text { hose carts, hose carriers }\end{array}$ \\
\hline $\begin{array}{c}\text { EUIPO } \\
4899233\end{array}$ & & Black & 2006 & $\begin{array}{l}\text { Renova- } \\
\text { Fábrica, PT }\end{array}$ & 16 toilet paper \\
\hline
\end{tabular}




\begin{tabular}{|c|c|c|c|c|}
\hline $\begin{array}{c}\text { EUIPO } \\
5298989\end{array}$ & Yellow & 2006 & $\begin{array}{c}\text { Jakob Maier, } \\
\text { GE }\end{array}$ & $\begin{array}{l}7 \text { fittings for milking } \\
\text { installations }\end{array}$ \\
\hline $\begin{array}{c}\text { EUIPO } \\
5983283\end{array}$ & Light Green & 2007 & BASF, GE & $\begin{array}{l}17 \text { boards of polystyrene } \\
\text { extruded foams for heat }\end{array}$ \\
\hline $\begin{array}{c}\text { EUIPO } \\
7114011\end{array}$ & Traffic Purple & 2008 & $\begin{array}{l}\text { Vallourec \& } \\
\text { Mannesmann, } \\
\text { FR }\end{array}$ & $\begin{array}{l}17 \text { Pipe end protectors (not of } \\
\text { metal) }\end{array}$ \\
\hline $\begin{array}{l}\text { CZ IPO } \\
316059\end{array}$ & Magenta & 2009 & $\begin{array}{c}\text { Deutsche } \\
\text { Telekom, GE }\end{array}$ & 3842 telecommunications \\
\hline $\begin{array}{l}\text { CZ IPO } \\
332507\end{array}$ & $\begin{array}{c}\text { Cyan/Magent } \\
\mathrm{a}\end{array}$ & 2009 & $\begin{array}{l}\text { PROFIMED } \\
\text { s.r.o., CZ }\end{array}$ & $\begin{array}{l}35 \text { business linked to dental } \\
\text { care } \\
44 \text { medical care - dental care }\end{array}$ \\
\hline $\begin{array}{c}\text { EUIPO } \\
10194835\end{array}$ & Red/Brown & 2011 & $\begin{array}{c}\text { Grundfos } \\
\text { Holding, DK }\end{array}$ & 7 circulator pumps \\
\hline $\begin{array}{c}\text { EUIPO } \\
11849791\end{array}$ & Green & 2013 & $\begin{array}{c}\text { CLAAS } \\
\text { KGaA mbH, } \\
\text { GE }\end{array}$ & $\begin{array}{l}7 \text { agricultural machines } \\
12 \text { tractors, trucks }\end{array}$ \\
\hline $\begin{array}{c}\text { EUIPO } \\
11886777\end{array}$ & $\begin{array}{l}\text { Heather } \\
\text { Violet }\end{array}$ & 2013 & $\begin{array}{l}\text { RUD Ketten } \\
\text { Rieger, GE }\end{array}$ & $\begin{array}{l}6 \text { round steel chains } \\
8 \text { devices for chains }\end{array}$ \\
\hline $\begin{array}{c}\text { EUIPO } \\
12886677\end{array}$ & Green & 2013 & $\begin{array}{l}\text { Bornack } \\
\text { GmbH, GE }\end{array}$ & $\begin{array}{c}9 \text { securing and rescue } \\
\text { apparatus for rappelling up or } \\
\text { down shafts }\end{array}$ \\
\hline $\begin{array}{c}\text { EUIPO } \\
12549218\end{array}$ & Gold/White & 2014 & Toshiba, JP & 9 notebook and tablets PCs \\
\hline $\begin{array}{l}\text { CZ IPO } \\
357967\end{array}$ & $\begin{array}{c}\text { Red/Magenta/ } \\
\text { Dots }\end{array}$ & 2015 & Zentiva, CZ & 5 medication reducing pain \\
\hline $\begin{array}{c}\text { EUIPO } \\
13852215\end{array}$ & Blue & 2015 & $\begin{array}{c}\text { Ziehl-Abegg, } \\
\text { GE }\end{array}$ & 7911 ventilations \\
\hline
\end{tabular}

Source: Authors' own processing based on the Czech IPO registry database $-\underline{w w w . u p v . c z}$

Obviously, the snap-shot of the current status quo of the colour trademark registrations is illustrative, but not indicative. In other words, the total number of 28 does not allow employing typical econometric and statistical methods, and basically only one piece of information can be extracted without the danger to be objected to by the random and standard deviation objections - the fact that basically all owners of single colour trademarks are wellknown large companies. Otherwise, it seems that no particular class of goods and services is preferred for a single colour trademark and no particular types of colours have been used.

Therefore, the exploration of data about the single colour trademarks needs to be approached and explored, not only from the statistical perspective, but, as well, a move has to be made to the dynamic perspective. In other words, we should not only ask what the single colour trademarks are, but, as well, how did they come to be colour trademarks? To put it in the strict 
legal context, the question can be rephrased - how did these large companies manage to pass the distinctiveness test and threshold so as to be allowed trademark registration?

\subsection{Single Colour Trademark Registration History - How Much Time and Effort Is Required to Pass the Distinctiveness Test}

On $29^{\text {th }}$ May 1995, Kraft Foods filed for single colour applications "Milka - Lilac/violet" in Switzerland and via WIPO they sought international protection for this trademark 644464 (114897) to be translated in national protection in designated countries and, shortly after, the file reached the Czech Republic as well. Between 1996 and 1998, the fight over the admissibility of the colour trademark and the very distinctiveness of "Milka - Lilac/violet" took place before the Czech IPO, which decided against it in 1999. Since the internal administrative appeal confirmed this rejection, Kraft Foods filed a lawsuit and the case reached the Czech Superior Court in Prague. The judges, with a brilliantly drafted judgment, reached the opposite result, they decided directly for Kraft Foods and, indirectly, for the registration of this trademark. The protection, i.e. the registration, was granted in 2002, which means that the international venue towards the protection in the Czech Republic took almost seven years. In contrast to this, on the $1^{\text {st }}$ of April, 1996, Kraft Foods applied for this colour as an EU trademark with a priority going back to 24th October 1995, under 31336. The EU trademark application process by OHIM successfully ended with the registration of 31336 Milka - Lilac/violet" in 1999, i.e. it took four years.

The historically second single colour trademark is 212787 and the application for it was filed by Deutsche Telekom in 1996 and was registered in 2004, i.e. it took four years. The third one, 396176, was filed in 1996 and registered in 2001, i.e. it took five years. The fourth one, 655019, was filed in 1996 and was registered in 2001, i.e. it also took five years. The fifth one, 747501, was filed in 1998 and registered in 2003, so the process took five years again, etc. However, the most recent single colour trademark successfully applied for and granted by CZ IPO, O-520137 (reg.357967) passed the registration process, including bringing evidence and proving the distinctiveness, in less than two years.

Again, since the total number of all single colour trademarks recognized by the EUIPO or CZ IPO enjoying the validity as of $15^{\text {th }}$ June 2017 is only 28 , the study of the registration process is not conclusive, but definitely more than just illustrative. Indeed, it is indicative at least with respect to the Czech national law and CZ IPO. Consequently, the OHIM was changed into EUIPO and the EU law on trademarks has been undergoing a reform, which started in 2015 and is in the process of taking effect. However, the Czech national law on trademarks has been set favourably for single colour trademarks for over one decade and, even though there are very few cases, the registration process can be successfully completed in less than two years. Further, out of these four "totally" (originally filed with the CZ IPO) Czech single colour trademarks, none needed to go to the court, i.e. the CZ IPO required and obtained sufficient evidence about the distinctiveness, and nothing more than a further requested or internal appeal were needed. Even more interestingly, these trademarks were, during the registration process, and even after it as well, attacked by third parties. Nevertheless, they have survived all these challenges and Table 2 summarizes the dynamics and national particularities of the successful single colour trademark applications filed first with the $\mathrm{CZ}$ IPO. 
Tab. 2: Single colour trademark filed first and registered with the CZ IPO as of 15th June 2017

\begin{tabular}{|c|c|c|c|c|c|c|}
\hline Trademark & Colour & Colour & $\begin{array}{c}\text { Filed/ } \\
\text { Priority }\end{array}$ & Registered & Owner & $\begin{array}{c}\text { Protected goods } \\
\text { and services }\end{array}$ \\
\hline $\begin{array}{c}\text { O-360082 } \\
304707\end{array}$ & & Red & 2004 & 2009 & Vodafone, CZ & 38 \\
\hline $\begin{array}{c}\text { O-470186 } \\
316059\end{array}$ & & Magenta & 2009 & 2011 & $\begin{array}{c}\text { Deutsche Telekom, } \\
\text { GE }\end{array}$ & 38,42 \\
\hline $\begin{array}{c}\text { O-471135 } \\
332507\end{array}$ & & $\begin{array}{c}\text { Cyan/ } \\
\text { Magenta }\end{array}$ & 2009 & 2011 & Profimed, CZ & 35,44 \\
\hline $\begin{array}{c}\text { O-520137 } \\
357967\end{array}$ & $\begin{array}{c}\text { Red/Mag } \\
\text { enta/Dot }\end{array}$ & 2015 & 2017 & Zentiva, CZ & 5 \\
\hline
\end{tabular}

Source: Authors' own processing based on the Czech IPO registry database $-\underline{w w w . u p v . c z}$

The analysis of "totally" Czech single colour trademarks and the Table 2 overview not only suggest that warm magenta-red colours seem to be the top candidate for single colour trademarks, perhaps following the milestone international-Czech single colour trademark "Milka - Lilac/violate" and that the large profit generating companies from telecommunications (by the way, the last from the Czech telecommunication trio, O2, has a colour trademark - consisting of a set of blue shades - as well) and pharmaceutical industries have the resources, capacity and know-how to pass the distinctiveness test and to get the single colour trademark. The Czech national inclination for warm colours, such as red, matches the general experience and knowledge that warm colours are perceived as stimulating, as opposed to cold colours, such as blue and green, which have a calming effect [2].

However and perhaps more importantly, it has been a matter of concern shared not only by many scholars stating that "colour should not be monopolized by big companies". In other words, there is a legitimate fear that the public domain is under pressure, especially in the context of the EU law on trademarks, with respect to not strongly distinctive signs, including colours. Certain voices are even being raised against the possibility of acquiring distinctiveness through use in trade [1]. However, the available data, including the above tables, indicate that these fears are linked only to rare application excesses and not to the systematic setting. It appears that CZ IPO manages very well to filter colour trademark applications and, despite perhaps more flexible legal wording (a colour instead of colours), the four colour trademarks are truly known to the large Czech public truly linking them to their owners and their goods and services. Naturally, a question can be raised about whether it is fair that, so far, with the CZ IPO and basically as well the EUIPO, only big companies prevail and manage to prove the distinctiveness of their single colour signs. Undoubtedly, the strategy EUROPE 2020 for smart, sustainable and inclusive growth appreciates small and medium sizes businesses ("SMEs"). However, the economic reality needs to be observed the distinctiveness needs to be established vis-à-vis to the public-at-large, and if there are only three telecommunication service providers and each of them uses one colour, then everybody in the country knows which colour goes to whom. This perhaps creates an impression of inherent injustice for SMEs producing and commercializing particular goods or services known to a small segment of the population, because these SMEs can hardly pass the distinctiveness test for a single colour trademark. In addition, it is argued that colours are 
more important for superficial choices when consumers do not spend too much time checking products [1], i.e. SMEs with particular goods; and services generally target and get attention of more attentive consumers. So the lack of a single colour trademark does not seem to be catastrophic for them. Indeed, adhering to a colour is generally beneficial for product categories of a dominant market leader, especially high-involvement categories [6].

Further, we should keep in mind that unconventional trademarks are true specialties difficult, rare and expensive, i.e. perhaps only the top companies from certain industries can reach them. Again, this is the economic reality and the law should not step heavily into it and artificially create some social engineering for SMEs. And who knows, perhaps, thanks to modern technologies, the internet and domain universe, special social media, perhaps some SMEs will manage it too. And if not, they have much a better chance to go for a colour combination trademark or a good colour-word logo.

Allowing trademark protection for colour(s) trademark which truly appeal to consumer and manifestly signify a specific source incentivizes the continued creation of attractive products [16] and reinforce healthy and informed competition. A single colour trademark deserves to belong in the plans and projects of Europe 2020 and definitely has its place on the Czech market.

\section{Conclusion}

Colour trademarks have existed, to a certain extent, for centuries and they and their fantastic potential got (re)discovered around 1995 and they became, along with other unconventional labelling signs, such as 3D, smell, taste, etc., hot candidates for signs to be allowed to pass the distinctiveness test and to be registered as trademarks. The strong demand by businesses pushed by the economic reality made first judges and then even legislatures change the legal setting and allow colours signs, even single colour signs, to be registered as EU trademark with EUIPO or Czech trademark with CZ IPO. Especially single colour trademarks are all consumers friendly, i.e. they are appreciated even by children and people with reading difficulties; they also have the potential to become a hallmark and referencing asset supporting market transparency nationally, regionally and even globally.

The static-substantive problem was resolved in an absolutely clear manner, since the analysis of the post-reform EU law on trademarks and the Czech law on trademark indisputably confirms that colours signs can be registered as trademarks, provided they satisfy general criteria for trademark registration, especially if they pass the distinctiveness test. The Czech legal wording even mentions the colour in singular! The dynamic-procedural problem is whether these legal provisions are dead letters or really useful vehicles, namely what was positively resolved too, i.e. the records on registration of EU trademarks and "totally" Czech trademarks reveals that colour trademarks are definitely part of both economic and law reality, i.e. approximately 150 of them are valid in the Czech Republic. The first trend to be observed consists in the shortening of the registration proceedings and elimination of the need to go to court, while the distinctiveness test seems to be vigorously applied. At the same time, the law is doing just a legal framework with objective rules and requirements hard to be met, and thus leading to a much higher rate of success by large companies than SMEs and in certain industries (telecommunication, pharmaceutical, chocolate). In any case, this is the economic reality and the law is set properly and it could be hardly suggested that it should be changed in order to make colour trademark registration easier for some and discriminate others. This would be as mixing in the selection of colours. Unlike the EU law distinctiveness test [1] which perhaps needs a serious readjustment, the Czech law one does not need any. Hence, the second trend is shaping of a typical single colour trademark, especially the Czech 
one, which is red-magenta-violet, owned by a large company and is linked to goods or services from the indicated industries.

In sum, a single colour trademark is an attractive and viable option for the Czech market, but it does not come "easily and for free". Businesses should study the legal framework and its application by the EUIPO and CZ IPO carefully and competent judges should create their "SWOT" analysis in this respect. A single colour trademark is definitely not for everyone and a combination of colours or colour wording logo could be an easier option. However, if the analysis reveals that the business has a single colour sign with strong distinctiveness features, it would be foolish to give a pass on the legal protection of such a supra attractive sign providing many marketing and referencing functions, serving both the business as well as consumers and even becoming a well-deserved valuable asset. Ave colourata nota! Ave colarata stigma!

\section{Acknowledgements}

This paper is based upon the Master Thesis of Anastasiia Dmitrieva, M.A., written and defended in 2017 (the thesis supervisor was JUDr. Radka MacGregor Pelikánová, Ph.D., LL.M., MBA). They both express their gratitude to the Anglo-American University, Prague, for the opportunity and resources allowing for researching this highly interesting and novel topic and publishing it.

\section{Literature}

[1] ANEMAET, L.: The Public Domain Is Under Pressure - Why We Should Not Rely on Empirical Data When Assessing Trademark Distinctiveness. International Review of Intellectual Property and Competition Law. DOI: 10.1007/s40319-016-0459-8

[2] BELLIZZI, J.; CROWLEY, A.S.; HASTY, R.W. The effects of color in store design. Journal of Retailing. 1983, Vol. 59, Issue 1, pp 21-45. ISSN 0022-4359.

[3] DMitrieVA, A.; PELIKÁNOVÁ, R.M.: The Global Good Present and Perhaps Even Better Future of Colour Trademark. AA Law Forum. 2017, No. 8, pp. 30-43. ISSN 1804-1094

[4] ELLIOTT, Ch.: Purple Pasts: Color Codification in the Ancient World. Law \& Social Inquiry. DOI: $10.1111 / \mathrm{j} .1747-4469.2008 .00097 . \mathrm{x}$

[5] KNAPP, V.: Teorie práva. $1^{\text {st }}$ edition. C. H. Beck, Praha, 1995. ISBN 80-7179-028-1.

[6] LABRECQUE, L.I.; MILNE, G.R.: To be or not be different: Exploration of norms and benefits of color differentiation in the marketplace. Marketing Letters. DOI: $10.1007 / \mathrm{s} 11002-012-9210-5$

[7] LlOYD, P. J.; VAUTIER, K. M.: Promoting Competition in Global Markets. A Multinational Approach. Edward Elgar, Cheltenham, 1999. ISBN 9781858988030. DOI: $\underline{10.4337 / 9781840647723}$

[8] LONG, D.: Resolving Trademark Duality in the Twenty-First Century: Making Trademarks Internet Ready. ACTA MUP. 2013, Issue 1, pp. 43-49. ISSN 1804-6932.

[9] LONG, D.: Rebooting trademarks for the twenty-first century. University of Louisville Law Review. 2011, Vol. 49, Issue 4, pp. 519-554. ISSN 1942-9266

[10] MATEJKA, J. Internet jako objekt práva - Hledání rovnováhy autonomie a soukromí. CZ.NIC, Praha, 2013. ISBN 978-80-904248-7-6. 
[11] PELIKÁNOVÁ, R. M.: Internet My Dearest, What Type of European Integration Is The Clearest? Acta Universitatis Agriculturae et Silviculturae Mendelianae Brunensis. 2013, Vol. LXI, Issue 7, pp. 2475-2481. ISSN 1211-8516.

[12] PELIKÁNOVÁ, R. M.; CÍSAŘOVÁ, J.: An Overview of the Concept of Good Morals in Czech Codices. AA Law Forum. 2014, No. 5, pp. 3-12. ISSN 1804-1094.

[13] SHAWN, M.: Global Society and International Relations: Sociological Concepts and Political Perspectives. $1^{\text {st }}$ Edition. Polity Press, Cambridge, 1994. ISBN 0745612113.

[14] SILVERMAN, D.: Doing Qualitative Research - A Practical Handbook. $4^{\text {th }}$ Edition. SAGE, London, 2013. ISSN 978-1446260159.

[15] Van HOREN, F.; PIETERS, R.: Consumer evaluation of copycat brands: The effect of imitation type. International Journal of Research in Marketing. DOI: $\underline{10.1016 / \text { j.ijresmar.2012.04.001 }}$

[16] WINCKEL, E.: Hardly a Black-and-White Matter: Analyzing the Validity and Protection of Single-Color Trademarks within the Fashion Industry. Vanderbilt Law Review. 2013, Vol. 66, No. 3, pp. 1015-1052. ISSN 0042-2533. 


\section{JEDNOBAREVNÉ OCHRANNÉ ZNÁMKY NEJEN NA SOUČASNÉM ČESKÉM TRHU}

Postmoderní globální společnost je poznamenána velmi intenzivní konkurencí, ve které je správné odkazování kritické. Konkurenční výhoda je zbytečná bez právně chráněné metody propojení podniku s jeho produkty. Tato metoda par excellence má podobu ochranné známky, která je jak referenčním nástrojem, tak nesmírně cenným nehmotným majetkem. Každá jurisdikce zajišt’uje registraci ochranných známek a je obtížné nalézt nové, atraktivní a univerzální označení, které by mohlo být registrováno v několika jurisdikcích, a stát se tak globální ochrannou známkou. Pro řešení tohoto problému jak právo EU, tak české právo nově výslovně umožňují nekonvenční ochranné známky, jako jsou barvy. Cílem tohoto příspěvku je velmi inovativní výzkum primárních a sekundárních údajů o jednobarevných registracích českých ochranných známek a souvisejících trendů ve světle hypotéz prokazujících, že jednobarevné ochranné známky jsou vnímány právem i ekonomikou jako více než životaschopná volba pro odkazování a marketing i jako majetek.

\section{EINFARBIGE SCHUTZMARKEN NichT NUR AUf DEM AKTUELLEN TSCHECHISCHEN MARKT}

Die postmoderne globale Gesellschaft zeichnet sich durch eine sehr intensive Konkurrenz aus, in der die richtige Referenzierung entscheidend ist. Ein Wettbewerbsvorteil ist nutzlos, ohne eine gesetzlich geschützte Methode, das Unternehmen mit seinen Produkten zu verknüpfen die Schutzmarke, die sowohl ein referenzierendes Werkzeug als auch ein äußerst wertvolles immaterielles Gut ist. Es ist äußerst schwierig, ein neues, attraktives und universelles Zeichen zu finden, das in mehreren Ländern registriert werden kann und somit zu einer globalen Marke wird. Deswegen erlauben sowohl das EU-Recht als auch das tschechische Recht ausdrücklich unkonventionelle Marken wie Farben. Das Ziel dieser Arbeit ist sehr innovativ und zukunftsweisend, nämlich die Erforschung von Primär- und Sekundärdaten über einfarbige tschechische Schutzmarken und verwandte Trends mit den Hypothesen, dass einfarbige Schutzmarke bei dem Recht und dir Ökonomie als eine lebensfähige Option für die Referenzierung, sowie ein Vermögenswert wahrgenommen werden.

\section{JEDNO KOLOROVE ZNAKI TOWAROWE NA AKTUALNYM RYNKU CZESKIM}

Postmodernistyczne społeczeństwo globalne charakteryzuje się bardzo silnej konkurencji, w prawidłowy odsyłania jest kluczowa. Przewagi konkurencyjnej jest bezużyteczny bez zastrzeżona metoda połączyć firmę z jej produktów - znak towarowy, który jest zarówno narzędziem katalogowanie i niezwykle cenny składnik wartości niematerialnych. Jest niezwykle trudno znaleźć nowy, atrakcyjny i uniwersalny charakter, który może być zarejestrowany w kilku krajach, a tym samym staje się globalną marką. Dlatego pozwalają zarówno prawa UE i prawa czeskiego jawnie niekonwencjonalne marek jak kolorach. Celem tej pracy jest bardzo innowacyjne i przyszłościowe, czyli eksploracja danych pierwotnych i wtórnych na monochromatycznych czeskich znaków towarowych i powiązanych trendów z hipotezą, że pojedynczy znak towarowy koloru w prawo i ci gospodarka jako realną opcją na przedstawieniu, jak również aktywa postrzegane być. 